\title{
Quantification of HSP70 Gene Expression and Determination of Capacitation Status of Magnetically Separated Cryopreserved Bovine Spermatozoa at Different Thawing Temperature and Time
}

(Kuantifikasi Ekspresi Gen HSP70 dan Penentuan Status Kapasitasi Sperma Lembu yang telah Dikrioawet pada Suhu Pencairan dan Masa yang Berbeza)

\author{
SYARIFAH FAEZAH SYED MOHAMAD*, SitI FATIMAH IBRAHIM, NUR HILWAN ISMAIL, KHAIRUL OSMAN, \\ FARAH HANAN FATHIHAH JAAFAR, CHEW FANG NANG \& FARIDA ZURAINA MOHD YUSOF
}

\begin{abstract}
The role of heat shock protein in reproduction is widely known as a molecular chaperone in aiding and repairing protein formation when stress occurred. The present objectives were to evaluate the effect of different thawing temperature and time on the expression of HSP70 gene expression and the capacitation status in cryopreserved bovine spermatozoa. Briefly, fresh ejaculates were obtained from three different adult bulls. The semen then underwent a sperm washing technique known as Magnetic Activated Cell Sorting System (MACS) and later on, cryopreserved. The sperm- containing straws were then thawed at five different thawing temperatures and time post-cryostorage; $20^{\circ} \mathrm{C}$ for $13 \mathrm{~s}, 37^{\circ} \mathrm{C}$ for $30 \mathrm{~s}, 40^{\circ} \mathrm{C}$ for $7 \mathrm{~s}, 60^{\circ} \mathrm{C}$ for $6 \mathrm{~s}$ and $80^{\circ} \mathrm{C}$ for $5 \mathrm{~s}$. The RNA was extracted from each of the sperm's pellets and converted to cDNA prior to the QPCR process. Capacitation status was then determined by means of CTC assay. The results showed that after the process of amplification, there is a significant different of HSP7O gene expression in MACS process samples when the thawing process was performed at $37^{\circ} \mathrm{C}$ for $30 \mathrm{~s}$, with $\mathrm{p}<0.05$. Furthermore, the CTC assay also showed that thawing at the same temperature gave less capacitated spermatozoa with $\mathrm{p}<0.05$. As a conclusion, MACS yield spermatozoa with a better expression of HSP7O gene and less capacitated spermatozoa when thawing was done at $37^{\circ} \mathrm{C}$ for $30 \mathrm{~s}$.
\end{abstract}

Keywords: CTC; heat-shock protein; MAC; sperm cryopreservation; thawing

ABSTRAK

Peranan protein kejutan haba dalam pembiakan telah diketahui secara meluas terutamanya sebagai molekul pengiring dalam membantu dan memperbaik pembentukan protein apabila tekanan berlaku. Objektif semasa adalah untuk menilai kesan suhu dan masa pencairan yang berbeza pada ekspresi gen protein HSP7O dan status kapasitasi sperma lembu yang telah dikrioawet. Secara ringkas, ejakulasi segar diperoleh daripada tiga lembu jantan dewasa yang berbeza. Air mani kemudiannya menjalani teknik penyediaan sperma yang dikenali sebagai Magnetic Activated Cell Sorting System (MACS) dan kemudiannya dikrioawet. Selepas itu, straw yang mengandungi sperma kemudiannya dicairkan pada lima suhu pencairan dan masa yang berbeza; $20^{\circ} \mathrm{C}$ selama $13 \mathrm{~s}, 37^{\circ} \mathrm{C}$ selama $30 \mathrm{~s}, 40^{\circ} \mathrm{C}$ selama $7 \mathrm{~s}, 60^{\circ} \mathrm{C}$ selama $6 \mathrm{~s}$ dan $80^{\circ} \mathrm{C}$ selama $5 \mathrm{~s}$. RNA kemudian diekstrak daripada pelet sperma dan ditukarkan kepada cDNA sebelum proses qPCR. Status kapasitasi kemudiannya telah dilakukan melalui esei CTC. Keputusan kajian menunjukkan bahawa selepas proses penguatan, ekspresi gen HSP70 terdapat perbezaan yang signifikan terhadap sperma yang telah menjalani MACS apabila pencairan dilakukan pada suhu $37^{\circ} \mathrm{C}$ selama $30 \mathrm{~s}$ dengan nilai $\mathrm{p}<0.05$. Tambahan pula, asai CTC juga menunjukkan bahawa pencairan pada suhu yang sama memberikan sperma yang kurang berkapasiti dengan nilai $\mathrm{p}<0.05$. Kesimpulannya, MACS boleh memberikan spermatozoa yang berkualiti baik dengan ekspresi HSP70 yang tinggi dan sperma yang kurang berkapasiti apabila pencairan dilakukan pada $37^{\circ} \mathrm{C}$ selama $30 \mathrm{~s}$.

Kata kunci: CTC; krioawet sperma; MACS; pencairan; protein kejutan haba

\section{INTRODUCTION}

Cryopreservation of semen is successfully used widely in the agricultural world due to the advantages it promises. Cryopreservation allows genetic improvement of agriculturally important species as well as controlling the spread of sexually transmitted disease. These factors are fundamentally important to succeed a sustainable agri-food industry (Bailey et al. 2000). From this method, farmers can now particularly select the semen from bulls that might not be available when required. Using the Assisted Reproductive Technique (ART) especially Artificial Insemination (AI), only one ejaculate from a genetically superior male can be used to impregnate multiple females in order to maximize the distribution of important and favorable genes. However, the process of thawing exerted some sort of stress towards these spermatozoa by impairing its motility and viability. For that reason, various kind of proteins is released in order to 
repair those damaged proteins. These proteins are known as the Heat-Shock Protein (HSP). These heat-shock proteins can be divided into different families which are based on their molecular weight measured in $\mathrm{kDa}$ rather than by their function. There are 27, 60, 70 and $90 \mathrm{kDa}$ HSP which is in small families. In reproduction, HSP60 and HSP70 are most important HSP, serving two major functions as a molecular chaperone and responding to cellular stress such as changes in temperature, free oxygen radical, viral and bacterial infection as well as heavy metals (Neuer et al. 2000). Studies have verified that HSP, particularly the most abundantly expressed $70 \mathrm{kDa}$ HSP, plays an important roles in acquiring thermal tolerance as an indicator (Huang et al. 2000; O'Hara et al. 2010). After ejaculation, semen is processed and prepared in order to obtained good quality sperm. The current standard of sperm preparations are the migration and sedimentation concept which is based on the sperm motility or density solely. However, the molecular event such as apoptosis is ignored, which may negatively impacts the fertility potential of the spermatozoa (Said et al. 2008). Therefore, the latest sperm separation technique called magnetic activated cell sorting system (MACS) was developed to avoid such impact. This system uses Annexin $\mathrm{V}$ microbeads which is a $35-36 \mathrm{kDa}$ phospholipid binding protein. When phosphatidylserine (PS) was exposed, these microbeads will bind to the apoptotic spermatozoa with deteriorated membranes so that it can be easily detected and separated from other spermatozoa. The objectives of this study were to quantify the expression of heat-shock protein (HSP70) gene and determine the capacitation status of spermatozoa after subjected to MACS and various thawing temperature and time.

\section{MATERIALS AND METHODS}

\section{SEMEN COLLECTION}

Fresh semen samples were collected from three adult bulls (Piedmontese) using artificial vagina at Institut Bioteknologi Veterinar Kebangsaan, (IBVK), Jerantut, Pahang. Three ejaculates were obtained and average yield per ejaculation was about $5 \mathrm{~mL}$.

\section{SEMEN PREPARATION}

The sperm suspension was divided into two separate fractions. The first fraction was subjected to magnetic activated cell sorting (MACS) system (MiltenyiBiotec, GmbH, Germany) mini macs kit followed by cryopreservation and thawing process, whereas the second fraction was cryopreserved without subjected to MACS system as the control group. The semen from the first fraction was separated based on the binding of Annexin $\mathrm{V}$ microbeads to phosphatidylserine that was externalized at the sperm's membrane. Briefly, the semen was subjected to centrifugation for $10 \mathrm{~min}$ at $300 \mathrm{rcf}$. The supernatant was then removed completely and the cell pellet was re-suspended in $80 \mu \mathrm{L}$ of Annexin V buffer per $10^{7}$ cells. $20 \mu \mathrm{L}$ of MACS Annexin V microbeads were added and the mixture was then incubated for $15 \mathrm{~min}$ in the dark at $6-12^{\circ} \mathrm{C}$. The sperms were then washed once with $1.5 \mathrm{~mL}$ buffer and re-suspended in $500 \mu \mathrm{L}$ of the same buffer. Cells were then placed on top of the separation column containing iron balls. The Annexin V microbeadslabelled spermatozoa (ANMB-positive) were retained in the separation column, which was placed in a magnet. The fraction with intact membranes that passed through the column was labeled as (ANMB-negative) fraction. This fraction was eluted and collected from the column. The magnetic field power used was 0.5 Tesla between the poles of the magnet and up to 1.5 Tesla within the iron globes of the column (Said et al. 2005).

\section{SEMEN CRYOPRESERVATION AND THAWING PROTOCOLS}

The second fraction (control group) and ANMB negative fraction were cryopreserved using Bioxcell $\AA$ extender (IMV, France). The concentration of semen mixture was determined using the (SpermaQue, German) and adjusted to 20 million spermatozoa per $0.25 \mathrm{~mL}$ straw. The mixture was placed in a chiller at $4^{\circ} \mathrm{C}$ for at least $3 \mathrm{~h}$. The sample was then transferred to $0.25 \mathrm{~mL}$ straws and put onto the vapor of liquid nitrogen $\left(-70^{\circ} \mathrm{C}\right)$ for $9 \mathrm{~min}$. Finally, the straws were then plunged into the liquid nitrogen (at $-196^{\circ} \mathrm{C}$ ) and stored in liquid nitrogen tanks.

Straws were then thawed in a water bath at $20^{\circ} \mathrm{C}$ for $13 \mathrm{~s}, 37^{\circ} \mathrm{C}$ for $30 \mathrm{~s}, 40^{\circ} \mathrm{C}$ for $7 \mathrm{~s}, 60^{\circ} \mathrm{C}$ for $6 \mathrm{~s}$ and $80^{\circ} \mathrm{C}$ for $5 \mathrm{~s}$, respectively. Thawing regimes were chosen based on previous studies and were slightly modified. These studies stated that various thawing rates would exert different effects towards sperms survival (Al-Badry 2012; Calamera et al. 2010; Rastegarnia et al. 2013). The temperatures chosen were ranged from as low as $20^{\circ} \mathrm{C}$ until $80^{\circ} \mathrm{C}$.

\section{EXTRACTION OF TOTAL RNA AND CDNA SYNTHESIS}

Conventional mortar and pestle technique combined with RNA extraction kit (Norgen Biotek, Canada) was used for RNA extraction. Briefly, 20 straws were thawed and centrifuged at $200 \mathrm{rcf}$ for $15 \mathrm{~min}$ in order to collect the pellet. The pellet was transferred into mortar and pestle with an appropriate amount of liquid nitrogen to cover up the sample. The sample was then grounded into a fine powder using pestle in liquid nitrogen. Liquid nitrogen was allowed to evaporate without allowing the sample to thaw. The next steps were performed under manufacturer instructions. The concentrations of extracted RNA were determined by using Nanodrop ND-1000 Spectrophotometer (Nanodrop Technologies Inc, USA). The RNA was converted to cDNA before preceded into PCR by using iScript cDNA synthesis kit (Biorad, CA). This step was performed by adding $4 \mu \mathrm{L}$ of $5 \mathrm{X}$ I Script buffer, $1 \mu \mathrm{L}$ iScript reverse transcriptase, $10 \mu \mathrm{L}$ RNA template and nuclease free water was added to total volume of $20 \mu \mathrm{L}$. The reaction protocol was carried out at $25^{\circ} \mathrm{C}$ for $5 \mathrm{~min}, 42^{\circ} \mathrm{C}$ for $30 \mathrm{~min}, 85^{\circ} \mathrm{C}$ for $5 \mathrm{~min}$ and was held at $4^{\circ} \mathrm{C}$ until taken to storage. Synthesized cDNA was stored at $-20^{\circ} \mathrm{C}$ until further use. 


\section{REAL-TIME POLYMERASE CHAIN REACTION (qPCR)}

The primers were designed using Primer 3 software and BLAST at NCBI webpage. The primers were obtained according to the sequence of Bos taurus $70 \mathrm{kDa}$ heat-shock protein (hsp 70) mRNA (forward), 5' CCTCGTACACCTGGATCAGC- 3' and (reverse), 5'- CTGATGGGGGACAAGTCG - 3'. As for housekeeping gene, Bos taurus glyceraldehyde3-phosphate dehydrogenase (GAPDH), mRNA, (forward) 5 '-CCACCACCCTGTTGCTGTAG-3, (reverse) 5'-CTGAGGACCAGGTTGTCTCC-3'. The reaction was performed in $25 \mu \mathrm{L}$ volumes using $12.5 \mu \mathrm{L}$ of IQ SYBR Green (Biorad, CA), $1.25 \mu \mathrm{L}$ of each forward and reversed primer ( $1^{\text {st }}$ Base, Malaysia), $2 \mu \mathrm{L}$ of cDNA and $8 \mu \mathrm{L}$ molecular biology grade water. The reaction condition was as follows: Enzyme activation at $95^{\circ} \mathrm{C}$ for $30 \mathrm{~s}, 95^{\circ} \mathrm{C}$ for 3 min, 49 cycles of denaturation at $95^{\circ} \mathrm{C}$ for $10 \mathrm{~s}$, annealing/ extension at $61.4^{\circ} \mathrm{C}$ for $30 \mathrm{~s}$ and melt curve from $55^{\circ} \mathrm{C}$ $95^{\circ} \mathrm{C}$ (in $0.5^{\circ} \mathrm{C}$ increment) for $10 \mathrm{~s} / \mathrm{step}$. The reaction took about $2 \mathrm{~h}$ and $30 \mathrm{~min}$. In qPCR, the chosen primer has an expected product size of 196 base pair. The Ct values were obtained from amplification chart while the melting curve was performed in order to check if the amplified fragments were correctly performed by applying the formula of gene expression $=2$ (Ct value housekeeping gene $-\mathrm{Ct}$ value gene of interest) .

\section{CHLORTETRACYCLINE (CTC) ASSAY}

Cryopreservation most likely will exert damages toward sperm's membrane integrity. One of the method used to assess cryo-capacitation like damage cause by cryopreservation is the Chlorotetracycline/Hoechst Staining Assay (CTC). Modified chlortetracycline staining protocol was used to determine the sperm cell capacitation status (Oh et al. 2010). Hundreds of fifty microliters of washed sperm were mixed with $3 \mu \mathrm{L}$ Propidium Iodide (PI) and three micro litres Hoechst342 (40 $\mu \mathrm{g} / \mathrm{mL})$ and incubated for $15 \mathrm{~min}$ at $37^{\circ} \mathrm{C}$ in the dark. $10 \mu \mathrm{L}$ of the mixture was added with $10 \mu \mathrm{L}$ of CTC solution $(805 \mu \mathrm{mol} / \mathrm{l}$ chlortetracycline and $5 \mathrm{mmol} / \mathrm{l}$ cysteine in chlortetracycline buffer containing $130 \mathrm{mmol} / \mathrm{l} \mathrm{NaCl}$ and $20 \mathrm{mmol} / \mathrm{l}$ Tris (Trizma base, pH7 .8) and fixed immediately with $10 \mu \mathrm{L}$ of $12.5 \%(\mathrm{w} / \mathrm{v}$ ) paraformaldehyde in $1 \mathrm{~mol} / \mathrm{l}$ Tris- $\mathrm{HCl}, \mathrm{pH} 8.0$. Then, the mixture was added with a droplet of $0.22 \mathrm{~mol}$ 1,4-diaza bicyclo [2.2.2] octane (DABCO) to prevent the fading of fluorescence stain. Two slides were prepared per treatment samples and analyzed within $2 \mathrm{~h}$ of preparation. Chlorotetracycline staining was assessed on live spermatozoa under blue-violet illumination (excitation at $330-380 \mathrm{~nm}$, emission at $420 \mathrm{~nm}$ ). Staining patterns observed was similar to those described by (Wang et al. 1995), namely: F, full fluorescence (uncapacitated); B, a fluorescence-free band in the post-acrosomal domain (capacitated); and AR, low fluorescence over the entire head with a band of bright fluorescence across the equatorial segment (acrosome reacted cells).

\section{STATISTICAL ANALYSIS}

Statistical analysis was performed using the SPSS software, version 14.0. The significant different of results between thawing procedures for sperm HSP70 gene expression and capacitation status for control and treatment groups were determined using two-way ANOVA. The p-value of 0.05 was considered as significant.

\section{RESULTS}

\section{RNA EXTRACTIONS FROM BULL SPERMS}

RNA bands were observed following gel electrophoresis $(0.5 \% \mathrm{w} / \mathrm{v})$ from control and treatment group. The smearing band may indicate that the RNA had undergone degradation process (Figure 1).

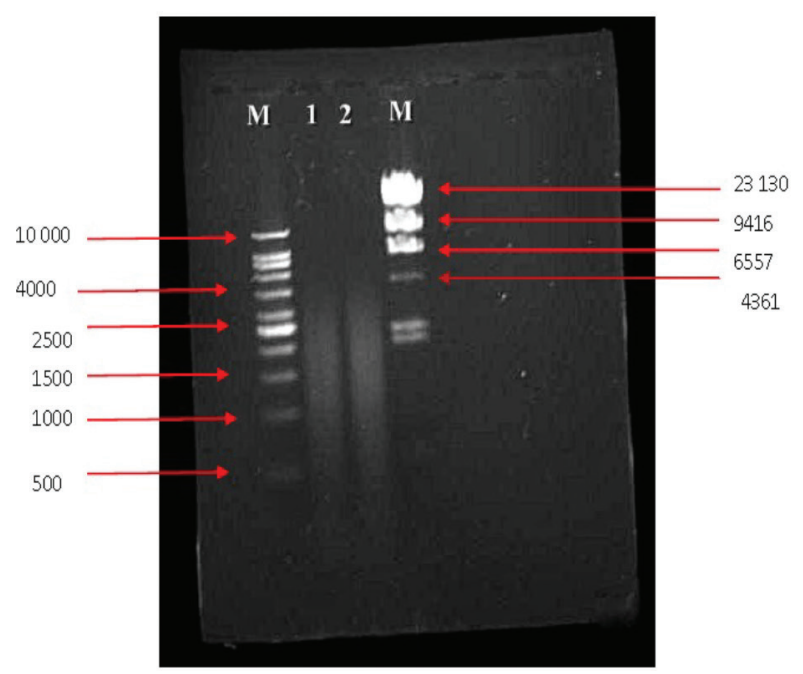

FIGURE 1. Analysis of extracted bull sperms RNA on a $0.5 \%$ agarose gel. Lane from extremely left: Lane 1: $1 \mathrm{~Kb}$ DNA ladder, Lane 2: RNA sample 1 (control), Lane 3: RNA sample 2 (treatment), Lane 4: Lambda HindIII marker 
RNA concentration of treatment group was the highest following cryopreservation and thawing process that was done at $37^{\circ} \mathrm{C}$ for $30 \mathrm{~s}$ with $83.84 \mathrm{ng} / \mu \mathrm{L}$. The high value of RNA purity indicates that the RNA was free from any contamination and excess ethanol (Table 1).

\section{DNA AMPLIFICATION USING REAL-TIME PCR ( $q P C R)$}

ANOVA test performed, a significant value was observed of the HSP70 gene expression when thawing was done at $37^{\circ} \mathrm{C}$ for $30 \mathrm{~s}$ and $60^{\circ} \mathrm{C}$ for $6 \mathrm{~s}$ with $p<0.05$ (Table 2). Thawing temperature of $30^{\circ} \mathrm{C}$ for $30 \mathrm{~s}$ showed the highest value of HSP70 gene expression in MACS treatment group.
qPCR PRODUCT CONFIRMATION ON 1.5\% AGAROSE GEL

After qPCR was carried out, the products were validated and confirmed on $1.5 \%(\mathrm{w} / \mathrm{v})$ of agarose gel electrophoresis under UV trans illuminator (Figure 2). The result indicated that all PCR products were successfully amplified with an expected base pair of 196 .

\section{CRYO-CAPACITATION LIKE DAMAGE BY CHLOROTETRACYCLINE/HOECHST STAINING ASSAY}

The result showed that the thawing temperature of $37^{\circ} \mathrm{C}$ for $30 \mathrm{~s}, 40^{\circ} \mathrm{C}$ for $7 \mathrm{~s}$ and $60^{\circ} \mathrm{C}$ for $6 \mathrm{~s}$ were significantly affects uncapacitated and capacitated sperms with $p<0.05$ (Table 3 ).

TABLE 1. Optical density (OD) readings for extracted RNA in control and treatment group

\begin{tabular}{lccccc}
\hline Sample id & $\mathrm{ng} / \mu \mathrm{l}$ & $\mathrm{A}_{260}$ & $\mathrm{~A}_{260 / 230}$ & $\mathrm{~A}_{260 / 280}$ & Constant \\
\hline RNA fresh sample & 12.68 & 0.317 & 0.38 & 1.56 & 40 \\
RNA $20^{\circ} \mathrm{C} 13$ s (control) & 27.05 & 0.676 & 0.46 & 1.78 & 40 \\
RNA $20^{\circ} \mathrm{C} 13$ s (treatment) & 33.47 & 1.272 & 0.64 & 1.82 & 40 \\
RNA $37^{\circ} \mathrm{C} \mathrm{30} \mathrm{s} \mathrm{(control)}$ & $26.33^{\mathrm{a}}$ & 0.658 & 0.21 & 1.83 & 40 \\
RNA $37^{\circ} \mathrm{C} 30 \mathrm{~s}$ (treatment) & $83.84^{\mathrm{b}}$ & 2.09 & 0.50 & 1.87 & 40 \\
RNA $40^{\circ} \mathrm{C} 7 \mathrm{sec}$ (control) & 18.25 & 0.456 & 0.076 & 1.80 & 40 \\
RNA $40^{\circ} \mathrm{C} 7 \mathrm{~s}$ (treatment) & 54.38 & 1.343 & 0.29 & 1.83 & 40 \\
RNA $60^{\circ} \mathrm{C} 6$ s (control) & 13.40 & 0.335 & 0.14 & 1.77 & 40 \\
RNA $60^{\circ} \mathrm{C} \mathrm{6} \mathrm{s} \mathrm{(treatment)}$ & 32.05 & 0.801 & 0.34 & 1.79 & 40 \\
RNA $80^{\circ} \mathrm{C} \mathrm{5} \mathrm{s} \mathrm{(control)}$ & 14.37 & 0.359 & 0.41 & 1.89 & 40 \\
RNA $80^{\circ} \mathrm{C} \mathrm{5} \mathrm{s} \mathrm{(treatment)}$ & 40.76 & 1.019 & 0.71 & 1.83 & 40 \\
\hline
\end{tabular}

${ }^{\mathrm{b}}$ is significantly higher than ${ }^{\mathrm{a}}$ with $p<0.05$

TABLE 2. Gene expression data

\begin{tabular}{|c|c|c|c|}
\hline Thawing temperature/time & Gene & $\mathrm{Ct}$ value $($ mean $\pm \mathrm{SEM})$ & $\begin{array}{l}\text { Relative gene expression } \\
\quad(\text { mean } \pm \mathrm{SEM})\end{array}$ \\
\hline RNA $20^{\circ} \mathrm{C} 13 \mathrm{~s}$ (control) & $\begin{array}{l}\text { HSP70 } \\
\text { GAPDH }\end{array}$ & $\begin{array}{l}29.912 \pm 1.456 \\
23.745 \pm 0.410\end{array}$ & $0.036 \pm 0.011$ \\
\hline RNA $20^{\circ} \mathrm{C} 13 \mathrm{~s}$ (treatment) & $\begin{array}{l}\text { HSP70 } \\
\text { GAPDH }\end{array}$ & $\begin{array}{l}29.827 \pm 1.448 \\
23.920 \pm 0.589\end{array}$ & $0.054 \pm 0.025$ \\
\hline RNA $37^{\circ} \mathrm{C} 30 \mathrm{~s}$ (control) & $\begin{array}{l}\text { HSP70 } \\
\text { GAPDH }\end{array}$ & $\begin{array}{l}29.664 \pm 0.568 \\
24.183 \pm 0.379\end{array}$ & $0.028 \pm 0.007^{\mathrm{b}}$ \\
\hline RNA $37^{\circ} \mathrm{C} 30 \mathrm{~s}$ (treatment) & $\begin{array}{l}\text { HSP70 } \\
\text { GAPDH }\end{array}$ & $\begin{array}{l}26.766 \pm 0.269 \\
23.091 \pm 0.414\end{array}$ & $0.097 \pm 0.027^{\mathrm{a}}$ \\
\hline RNA $40^{\circ} \mathrm{C} 7 \mathrm{sec}$ (control) & $\begin{array}{l}\text { HSP70 } \\
\text { GAPDH }\end{array}$ & $\begin{array}{c}29.151 \pm 0.564 \\
25.04 \pm 0.423\end{array}$ & $0.081 \pm 0.025$ \\
\hline RNA $40^{\circ} \mathrm{C} 7 \mathrm{~s}$ (treatment) & $\begin{array}{l}\text { HSP70 } \\
\text { GAPDH }\end{array}$ & $\begin{array}{l}26.944 \pm 0.177 \\
22.341 \pm 0.175\end{array}$ & $0.041 \pm 0.001$ \\
\hline RNA $60^{\circ} \mathrm{C} 6 \mathrm{~s}$ (control) & $\begin{array}{l}\text { HSP70 } \\
\text { GAPDH }\end{array}$ & $\begin{array}{l}29.123 \pm 0.436 \\
24.616 \pm 0.178\end{array}$ & $0.048 \pm 0.008^{b}$ \\
\hline RNA $60^{\circ} \mathrm{C} 6 \mathrm{~s}$ (treatment) & $\begin{array}{l}\text { HSP70 } \\
\text { GAPDH }\end{array}$ & $\begin{array}{l}27.348 \pm 0.112 \\
23.388 \pm 0.142\end{array}$ & $0.067 \pm 0.009^{\mathrm{a}}$ \\
\hline RNA $80^{\circ} \mathrm{C} 5 \mathrm{~s}$ (control) & $\begin{array}{l}\text { HSP70 } \\
\text { GAPDH }\end{array}$ & $\begin{array}{l}28.836 \pm 0.183 \\
24.627 \pm 0.429\end{array}$ & $0.07 \pm 0.023$ \\
\hline RNA $80^{\circ} \mathrm{C} 5 \mathrm{~s}$ (treatment) & $\begin{array}{l}\text { HSP70 } \\
\text { GAPDH }\end{array}$ & $\begin{array}{l}27.619 \pm 0.234 \\
22.857 \pm 0.219\end{array}$ & $0.038 \pm 0.005$ \\
\hline
\end{tabular}

${ }^{\mathrm{a}}$ is significantly higher than ${ }^{\mathrm{b}}$ with $p<0.05$ 


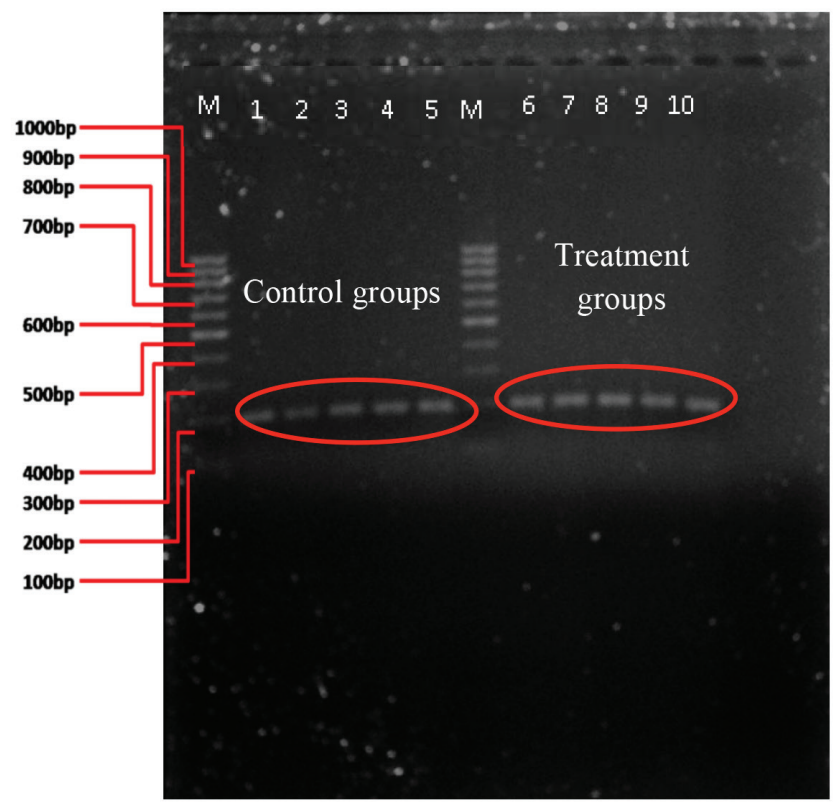

$\mathrm{M}=100 \mathrm{bp}$ DNA ladder. Lane $1=\mathrm{PCR}$ products from sperms sample in control group thawed at $20^{\circ} \mathrm{C}$. Lane $2=\mathrm{PCR}$ products from sperms sample in control group thawed at $37^{\circ} \mathrm{C}$. Lane $3=$ PCR products from sperms sample in control group thawed at $40^{\circ} \mathrm{C}$. Lane $4=\mathrm{PCR}$ products from sperms sample in control group thawed at $60^{\circ} \mathrm{C}$. Lane $5=\mathrm{PCR}$ products from sperms sample in control group thawed at $80^{\circ} \mathrm{C}$. Lane $6=\mathrm{PCR}$ products from sperms sample in treatment group thawed at $20^{\circ} \mathrm{C}$. Lane $7=\mathrm{PCR}$ products from sperms sample in treatment group thawed at $37^{\circ} \mathrm{C}$. Lane $8=\mathrm{PCR}$ products from sperms sample in treatment group thawed at $40^{\circ} \mathrm{C}$. Lane $9=\mathrm{PCR}$ products from sperms sample in treatment group thawed at $60^{\circ} \mathrm{C}$. Lane $10=\mathrm{PCR}$ products from sperms sample in treatment group thawed at $80^{\circ} \mathrm{C}$

FIGURE 2. Analysis of qPCR products from control and treatment groups for various thawing temperatures. Estimated product sizes are 196 base pair

TABLE 3. Mean percentage of uncapacitated and capacitated sperm in control and treatment group

\begin{tabular}{|c|c|c|}
\hline & $\begin{array}{l}\text { Uncapacitated sperm percentage } \\
(\%) \text { mean }\end{array}$ & $\begin{array}{c}\text { Capacitated sperm percentage } \\
\text { (\%) mean }\end{array}$ \\
\hline $20^{\circ} \mathrm{C} 13 \mathrm{~s}$ (control) & 54.50 & 36.17 \\
\hline $20^{\circ} \mathrm{C} 13 \mathrm{~s}$ (treatment) & 47.83 & 31.33 \\
\hline $37^{\circ} \mathrm{C} 30 \mathrm{~s}$ (control) & $22.33^{\mathrm{a}}$ & $61.83^{\mathrm{b}}$ \\
\hline $37^{\circ} \mathrm{C} 30 \mathrm{~s}$ (treatment) & $50.67^{\mathrm{b}}$ & $28.33^{\mathrm{a}}$ \\
\hline $40^{\circ} \mathrm{C} 7 \mathrm{~s}$ (control) & $23.5^{\mathrm{a}}$ & $60.33^{\mathrm{b}}$ \\
\hline $40^{\circ} \mathrm{C} 7 \mathrm{~s}$ (treatment) & $41.5^{\mathrm{b}}$ & $39.33^{\mathrm{a}}$ \\
\hline $60^{\circ} \mathrm{C} 6 \mathrm{~s}$ (control) & $20.59^{\mathrm{a}}$ & $64.50^{\mathrm{b}}$ \\
\hline $60^{\circ} \mathrm{C} 6 \mathrm{~s}$ (treatment) & $52.33^{\mathrm{b}}$ & $29.67^{\mathrm{a}}$ \\
\hline $80^{\circ} \mathrm{C} 5 \mathrm{~s}$ (control) & 34.5 & 52.00 \\
\hline $80^{\circ} \mathrm{C} 5 \mathrm{~s}$ (treatment) & 39.5 & 40.50 \\
\hline
\end{tabular}

${ }^{\mathrm{b}}$ is significantly higher than ${ }^{\mathrm{a}}$ with $p<0.05$

\section{DISCUSSION}

The survival of spermatozoa after freezing-thawing process depends on the plasma membrane as it is the most crucial and regarded as the primary site of cryoinjury (Söderquist et al. 1997). There are a few techniques for sperm preparations before cryopreservation and one of the latest technique is using magnetic separation. Sample form MACS procedure had proven that their membranes are more intact as there were no phosphatidylserine being exposed (Degheidy et al. 2015). The principle underlying this tool is the utilization of magnetic micro-particles conjugated with specific antibodies. Untagged cells are not influenced by the magnetic field and can be used directly for insemination (Kang \& Park 2004). Externalisation of plasma membrane Phosphatidylserine (PS) during apoptosis is an oxidative signalling pathway which is identified as one of the earliest and prominent features of apoptosis. In present study, sperms were magnetically labelled with Annexin V microbeads and by-passed through a MACS column, which was placed in the magnetic field of a MACS separator. Cells with externalized PS were tagged, separated from the normal healthy cells and then flushed out from the system. As a result, only good and viable cells were collected for cryopreservation (Dirican et al. 2008). According to Gilbert et al. (2007), ejaculated spermatozoa were 
reported to contain $0.0018 \mathrm{pg}$ of RNA per spermatozoon. RNA extraction is a challenging procedure to perform in spermatozoa. This might happen due to the highly differentiated and specialized cells along with the sturdiness of the sperm's membrane itself (Roostaei et al. 2008). Even though sperm is a single and simple cell, its role and composition can suit any challenges during its way to fertilize the oocyte, transporting its paternal genome. One of which is by having an intact sperm cap called acrosome that contains a lot of PUFA to facilitate sperm's fluidity and also the principle piece that aids the movement towards the oocytes. Present study showed only a smear of RNA when visualized on agarose gel after the extraction process. This observation was in agreement with previous reports (Grunewald et al. 2005; Ostermeier et al. 2002). According to Grunewald et al. (2005), mature spermatozoa do not transcribe novel RNA. A smear of RNA obtained during an extraction from human spermatozoa indicated that spermatozoa were free of distinct bands of $28 \mathrm{~S}$ and $18 \mathrm{~S}$ ribosomal RNAs. The present result showed that between the control and treatment groups, RNA yield were more abundant in the treatment groups for all thawing conditions. Furthermore, RNA concentration in treatment group was the highest when thawed at $37^{\circ} \mathrm{C}$ for $30 \mathrm{~s}$ with the concentration of $83.84 \mathrm{ng} / \mu \mathrm{L}$ and 1.87 of purity at the wavelength of $\mathrm{A}_{260 / 280}$. This showed that at $37^{\circ} \mathrm{C}$, RNA recovery was at its maximum. It is well-accepted that cells are functioning optimally at body temperature which is $37^{\circ} \mathrm{C}$. This showed that by combining MACS separation system and thawing temperature at $37^{\circ} \mathrm{C}$ for $30 \mathrm{~s}$, it yields higher RNA concentration. Normally, multi-cell organisms react to heat or other stresses by inducing the synthesis of unique proteins groups generally referred to as heatshock proteins or HSPs. Previous studies stated that HSP70 plays an important role as an indicator of thermo tolerance and as a molecular chaperone that functions in aiding and repairing in protein formation (Guo et al. 2010; Piterková et al. 2013). Hence, by quantifying the expression of HSP70 gene, can be directly relating to the semen quality, particularly on its capacitation status. In ANOVA test, we observed that the expression of HSP70 gene were significant at $37^{\circ} \mathrm{C}$ for $30 \mathrm{~s}$ and at $60^{\circ} \mathrm{C}$ for $6 \mathrm{~s}$ with $p<0.05$ in treatment groups. This is probably due to the fact that the RNA concentration in treatment groups were higher as compared to the control group. Moreover, when temperature is higher than $37^{\circ} \mathrm{C}$, protein denaturation will start to occur and eventually lead to the degradation of this protein. Contri et al. (2010) and Monterroso et al. (1995) found out that those bull spermatozoa that were exposed to heat shock at $42^{\circ} \mathrm{C}$ and $43^{\circ} \mathrm{C}$ have a decreased viability and motility as compared to the lower temperature of $39^{\circ} \mathrm{C}$. The ability of HSP to maintain cell survival was detected by the inhibition of apoptosis marker; The Caspase Activation. HSP can impact the 'intrinsic'; the mitochondrial-dependent pathway and the 'extrinsic'; death receptor-mediated pathway of apoptosis. Hence, it is suggested that thawing cryopreserved sperms at $37^{\circ} \mathrm{C}$ for $30 \mathrm{~s}$, this procedure can facilitate the HSPs to function properly as a chaperon and non-apoptotic role. It is now recognized that the surviving population of spermatozoa is compromised as a result of capacitation-like changes (Bailey et al. 2000; Yeste 2016). In the present study, capacitation status of MACS treated group and control group were assessed using CTC assay. The results indicated that treatment groups produced more uncapacitated sperm as compared to the control group after subjected to different thawing regimes. During the capacitation and acrosomal reaction, PS did not expose on the surface of viable sperm cells. Kurz et al. (2005) mentioned that PS is localized in the cytoplasmic leaflet of the plasma membrane as well as on the outer acrosomal membrane. This clarified and proven current result that during the capacitation process and acrosomal reaction, more uncapacitated cells were revealed after MACS separation. The results showed that thawing at $37^{\circ} \mathrm{C}, 40^{\circ} \mathrm{C}$ and $60^{\circ} \mathrm{C}$ yield significant results in treatment groups. Thawing at either one of these temperatures yields spermatozoa that is yet to be capacitated because the process of capacitation must occur at exactly specified time inside the female oviduct tract in order for fertilization to occur. Any event preceding fertilization that occurs at the wrong time and the wrong place will results in poor fertilization rates (Simon et al. 2011). Membrane destabilization causes the sperm to exhibit cryo-capacitation with B pattern that favour calcium influx to the cell during cryopreservation (Maxwell \& Johnson 1997). Moreover, the capacitation process is believed to have a relationship with apoptosis. Reactive oxygen species (ROS) are essential in regulating sperm function, but it also act as a two-edge sword (Aitken 2011). At low levels, ROS are needed to promote cholesterol oxidation and tyrosine phosphorylation events that support capacitation. However, excessive production of ROS can lead to a state of oxidative stress that affects sperm function.

\section{CONCLUSION}

In conclusion, the quality of bull's spermatozoa can also be accessed through the quantification of the HSP70 gene expression rather than the motility alone. Expression of this gene coupled with the capacitation status concluded that the MACS is an ideal sperm preparation technique prior to cryopreservation. By choosing the suitable thawing temperature which is at $37^{\circ} \mathrm{C}$ for $30 \mathrm{~s}$, the spermatozoa population produced is at its highest HSP70 gene expression and creating less capacitated sperms. However, the fertility potential of this MACS sperm population has yet to be determined. This could be achieved through further research in the future.

\section{ACKNOWLEDGEMENTS}

The researchers are thankful to the Ministry of Science and Technology (MOSTI), Universiti Kebangsaan Malaysia 
(UKM), Universiti Teknologi MARA (UiTM) and Agrobiotech Institute for the research grants given: 10-05-ABI-AB040 and 600-RMI/ST/DANA 5/3/Dst (263/2009). Special thanks to Institute of Veterinary, Jerantut, Pahang for assisting in semen sampling and technical supports.

\section{REFERENCES}

Aitken, R.J. 2011. The capacitation-apoptosis highway: Oxysterols and mammalian sperm function. Biology of Reproduction 85(1): 9-12.

Al-Badry, K.I. 2012. Effect of various thawing times and temperatures on frozen semen quality of friesian bulls in Iraq. Int. J. Anim. Veter. Adv. 4(6): 384-388.

Bailey, J.L., Bilodeau, J.F. \& Cormier, N. 2000. Semen cryopreservation in domestic animals: A damaging and capacitating phenomenon. Journal of Andrology 21(1): 1-7.

Calamera, J.C., Buffone, M.G., Doncel, G.F., Brugo-Olmedo, S., de Vincentiis, S., Calamera, M.M., Storey, B.T. \& Alvarez, J.G. 2010. Effect of thawing temperature on the motility recovery of cryopreserved human spermatozoa. Fertility and Sterility 93(3): 789-794.

Contri, A., Claudio, V., Massimo, F., Laura, W. \& Augusto, C. 2010. Effect of semen preparation on casa motility results in cryopreserved bull spermatozoa. Theriogenology 74(3): 424-435.

Degheidy, T.H., Abdelfattah, Seif, A., Albuz, F.K., Gazi, S. \& Abbas, S. 2015. Magnetic activated cell sorting: an effective method for reduction of sperm DNA fragmentation in varicocele men prior to assisted reproductive techniques. Andrologia 47(8): 892-896.

Dirican, E.K., Özgün, O.D., Akarsu, S., Akın, K.O., Ercan, Ö., Uğurlu, M., Çamsarı, C., Kanyılmaz, O., Kaya, A. \& Ünsal, A. 2008. Clinical outcome of magnetic activated cell sorting of non-apoptotic spermatozoa before density gradient centrifugation for assisted reproduction. Journal of Assisted Reproduction and Genetics 25(8): 375-381.

Gilbert, I., Bissonnette, N., Boissonneault, G., Vallee, M. \& Robert, C. 2007. A molecular analysis of the population of mRNA in bovine spermatozoa. Reproduction 133(6): 1073-1086.

Grunewald, S., Paasch, U., Glander, H.J. \& Anderegg, U. 2005. Mature human spermatozoa do not transcribe novel RNA. Andrologia 37(23): 69-71.

Guo, H., Xu, Y.M., Ye, Z.Q., Yu, J.H., Fu, Q., Sa, Y.L., Hu, X.Y. \& Song, L.J. 2010. Heat-shock protein 70 expression in the seminal plasma of patients with chronic bacterial prostatitis and chronic prostatitis/chronic pelvic pain syndrome. Prostate Cancer and Prostatic Diseases 13(4): 338-342.

Huang, S.Y., Kuo, Y.H., Lee, Y.P., Tsou, H.L., Lin, E.C., Ju, C.C. \& Lee, W.C. 2000. Association of heat shock protein 70 with semen quality in boars. Animal Reproduction Science 63(3-4): 231-240

Kang, J.H. \& Park, J.K. 2005. Technical paper on microfluidic devices-cell separation technology. Asia Pacific Biotech News 9(21): 1135-1146.

Kurz, A., Viertel, D., Herrmann, A. \& Müller, K. 2005. Localization of phosphatidylserine in boar sperm cell membranes during capacitation and acrosome reaction. Reproduction 130(5): 615-626.

Maxwell, W.M.C. \& Johnson, L.A. 1997. Chlortetracycline analysis of boar spermatozoa after incubation, flow cytometric sorting, cooling, or cryopreservation. Molecular Reproduction and Development 46(3): 408-418.

Monterroso, V.H., Drury, K.C., Ealy, A.D., Edwards, J.L. \& Hansen, P.J. 1995. Effect of heat shock on function of frozen/thawed bull spermatozoa. Theriogenology 44(7): 947-961.

Neuer,A., Spandorfer, S.D., Giraldo, P., Dieterle, S., Rosenwaks, Z. \& Witkin, S.S. 2000. The role of heat shock proteins in reproduction. Human Reproduction Update 6(2): 149-159.

Oh, S.A., Park, Y.J., You, Y.A., Mohamed, E.A. \& Pang, M.G. 2010. Capacitation status of stored boar spermatozoa is related to litter size of sows. Animal Reproduction Science 121(1): 131-138

O'Hara, L., Hanrahan, J.P., Richardson, L., Donovan, A., Fair, S., Evans, A.C.O. \& Lonergan, P. 2010. Effect of storage duration, storage temperature, and diluent on the viability and fertility of fresh ram sperm. Theriogenology 73(4): 541-549.

Ostermeier, G.C., Dix, D.J., Miller, D., Khatri, P. \& Krawetz, S.A. 2002. Spermatozoal RNA profiles of normal fertile men. The Lancet 360(9335): 772-777.

Piterková, J., Lenka, L., Barbora, M., Aleš, L. \& Petřivalský, M. 2013. Nitric oxide and reactive oxygen species regulate the accumulation of heat shock proteins in tomato leaves in response to heat shock and pathogen infection. Plant Science 207: 57-65.

Rastegarnia, A., Abdolhossein, S., Tohid, R.T., Bita, E. \& Vahid, S. 2013. Effect of different thawing rates on post-thaw viability, kinematic parameters, and chromatin structure of buffalo (Bubalus bubalis) spermatozoa. Cell Journal (Yakhteh) 14(4): 306-313.

Roostaei, M., Nikbakht, G.H., Baghbanzadeh, A. \& Tajik, P. 2008. RNA extraction and leptin receptor mRNA detection in bull ejaculated spermatozoa. J. Vet. Res. 63(2): 41-46.

Said, T.M., Agarwal, A., Zborowski, M., Grunewald, S., Glander, H.J. \& Paasch, U. 2008. Utility of magnetic cell separation as a molecular sperm preparation technique. Journal of Andrology 29(2): 134-142.

Said, T.M., Grunewald, S., Paasch, U., Rasch, M., Agarwal, A \& Glander, H.J. 2005. Effects of magnetic-activated cell sorting on sperm motility and cryosurvival rates. Fertility and Sterility 83(5): 1442-1446.

Simon, L., Deborah, L., Joanne, M. \& Sheena, E.M.L. 2011 Sperm DNA damage measured by the alkaline comet assay as an independent predictor of male infertility and in vitro fertilization success. Fertility and Sterility 95(2): 652-657.

Söderquist, L., Madrid-Bury, N. \& Rodriguez-Martinez, H. 1997. Assessment of ram sperm membrane integrity following different thawing procedures. Theriogenology 48(7): 1115-1125.

Wang, W.H., Abeydeera, L.R., Fraser, L.R. \& Niwa, K. 1995. Functional analysis using chlortetracycline fluorescence and in vitro fertilization of frozen-thawed ejaculated boar spermatozoa incubated in a protein-free chemically defined medium. Reproduction 104(2): 305-313.

Yeste, M. 2016. Sperm cryopreservation update: Cryodamage, markers, and factors affecting the sperm freezability in pigs. Theriogenology 85(1): 47-64.

Syarifah Faezah Syed Mohamad

Department of Biology, Faculty of Applied Sciences Universiti Teknologi MARA 
26400 Bandar Tun Abd Razak Jengka, Pahang Darul Makmur Malaysia

Nur Hilwan Ismail, Farida Zuraina \& Mohd Yusof Department of Biology, Faculty of Applied Sciences Universiti Teknologi MARA

40450 Shah Alam, Selangor Darul Ehsan Malaysia

Siti Fatimah Ibrahim, Farah Hanan Fathihah Jaafar \& Chew Fang Nang

Department of Physiology

Faculty of Medicine, UKM Medical Centre

Level 18, Pre-Clinical Building

Jalan Yaacob Latif, Bandar Tun Razak

56000 Cheras, Kuala Lumpur, Federal Territory

Malaysia
Khairul Osman

Faculty of Health Sciences

Universiti Kebangsaan Malaysia

Jalan Raja Muda Abdul Aziz

50300 Kuala Lumpur, Federal Territory

Malaysia

*Corresponding author; email: sharifahfaezah@pahang.uitm. edu.my

Received: 23 November 2015

Accepted: 10 January 2018 